\title{
Correction to: Optimized cloud-based scheduling for protein secondary structure analysis
}

Marco Ferretti ${ }^{1}$ Luigi Santangelo ${ }^{1} \cdot$ Mirto Musci $^{1}$

Published online: 17 June 2019

๑) Springer Science+Business Media, LLC, part of Springer Nature 2019

\section{Correction to: The Journal of Supercomputing https://doi.org/10.1007/s11227-019-02859-w}

Mirto Musci was not listed among the authors. The original article has been corrected.

Publisher's Note Springer Nature remains neutral with regard to jurisdictional claims in published maps and institutional affiliations.

The original article can be found online at https://doi.org/10.1007/s11227-019-02859-w.

Luigi Santangelo

luigi.santangelo@unipv.it

Marco Ferretti

marco.ferretti@unipv.it

Mirto Musci

mirto.musci@unipv.it

1 Department of Electrical, Computer and Biological Engineering, University of Pavia, Pavia, Italy 